oxygen supplied to the Air Ministry for high flying, it was not possible to say with any degree of certainty what was the loss (if any) on sales of oxygen for medical purposes in the strict sense of the term. The records of the company showed an average loss of $11 \%$ on cost for medical oxygen in all forms, including liquid oxygen for high flying, and there did not seem to the Commission to be any justification for any losses sustained on the sales of medical oxygen being in effect carried by the industrial consumers. They recommended that published price scales for medical oxygen should be prepared on the same lines as for industrial oxygen.

\section{Commission's Conclusion}

"We find that the British Oxygen Company charges unjustifiably high prices for oxygen-and that this operates and may be expected to operate against the public interest," states the Commission in its conclusions as to price. And further on, when dealing with the monopoly position which the company has built up, it is stated that the British Oxygen Company had taken advantage of the position to charge prices which the Commission regarded as unjustifiably high, and had pursued a price policy which was in other respects open to objection, and that all those things operated against the public interest and might be expected to continue to operate against them unless changes were made and safeguards introduced.

\section{Nova et Vetera}

\section{WILLIAM HILLARY, M.D. (1697-1763)}

William Hillary was one of the first physicians to attempt to correlate illness with climatic conditions. He was a careful and systematic observer of the weather and its effect upon prevalent diseases. He also wrote one of the earliest books to deal specifically with tropical disease, his Observations on the Changes of the Air, and the Concomitant Epidemical Diseases, in the Island of Barbados ... being published in London in 1759. This work included one of the original and most accurate descriptions of tropical sprue. Apart from these bare facts, however, little has been known of the life and work of William Hillary. His publications On the Small-pox, Diseases in Barbados, and Means of Improving Medical Knowledge may be consulted in libraries, but they contain little or no biographical detail. Who was this intriguing eighteenth-century physician? Who were his friends? Where did he come from?

Some of these questions have been answered during a recent survey of the correspondence of John Fothergill (1712-80), the famous Quaker physician. William Hillary was well known to this philanthropic doctor, for in a letter written to his brother Alexander in Wensleydale, Yorkshire, and dated July 11, 1746, Fothergill discussed Dr. Hillary and his intended voyage to the Barbados. "Whilst he was here," Fothergill wrote, "news came of the Death of the only eminent Physician at Barbados: I procured him an interview with a person who gave him an exact account of the affairs of that Island, he likewise spoke with several others who jointly recommended the place as much preferable to Jamaica .... there are several Meetings, the Island pleasant and healthy." Other letters included Fothergill's "kind love" to the Hillary family, and in November. 1746. he told his brother that he was glad that "Dr. Hillary's relations were satisfied with the part that.I acted in his affairs."

These letters do more than indicate that Fothergill knew Hillary well. that he took an active part in helping him to secure his post as physician in Barbados, and that Hillary too was a Quaker. They also suggest that the Hillary family was well known to Alexander Fothergill, living at Carr End in the wild and isolated beauty of Wensleydale, and that the Hillary family probably lived somewhere close by. They lived, in fact, in the Wensleydale village of Burtersett, where Hillary Hall still stands to-day, two or three miles from the Fothergill home at Carr End; and a search through Quaker records reveals that William, the son of John and Mary Hillary, was born on January 17, 1697 , a winter's day when the snow must have lain deep in Wensleydale.

Apart from his Yorkshire origin, William Hillary had another link with John Fothergill, for he worked in Bradford with the same apothecary, Benjamin Bartlett, to whom Dr. Fothergill later served his apprenticeship. He took his medical degree at Leyden in 1722, at that time the acknowledged centre of medical learning in Europe, graduating M.D. with a dissertation on intermittent fevers. He then became a physician in Ripon, Yorkshire, but in 1734 moved on to Bath. His situation there, however, was "not the most agreeable nor the prospect very pleasant," and for these reasons he went to Barbados in 1747, where his observations of the weather and the prevalent diseases occupied him from 1752 to 1757 . He returned to London in 1758. living quietly in retirement until his death on April 25, 1763.

Hillary and Fothergill were by no means the only wellknown physicians of the eighteenth century who had associations with the Yorkshire Dales. John Dawson (17341820) and John Haygarth (1740-1827) came from near-by Garsdale, and John Coakley Lettsom (1744-1815) was apprenticed to an apothecary, Abraham Sutcliff. in Settle, Ribblesdale. Further afield, Anthony Askew (1722-74), one of the owners of the famous gold-headed cane, was born in Kendal, over the border in Westmorland, but, like Fothergill and Haygarth, he was educated at Sedbergh School in Yorkshire. Among this illustrious company of Dales doctors William Hillary may claim an honoured place. He was a physician whose accuracy of observation and therapeutic skill were actuated by a constant search after perfection. His philosophy and his scientific approach to the practice of medicine cannot be better described than in the words of the introduction to his Rational and Mechanical Essay on the Smallpox, written whilst he was in practice in Ripon. This work was published later in 1735. An extract from his introduction follows:

"It appears how necessary it is for a Physician, who would be successful in his Practice, or make any tolerable Figure in his Profession, to be well acquainted with the structure of the Human Body, the use of all its Parts, the Principles of Mechanical Powers, the Laws of Motion and Hydraulics, with a sufficient skill in Geometry and Mathematics, to apply them ; as well as a knowledge of Chymystry, Pharmacy, and the Virtues and Doses of Medicines. For it is by a proper Use and Application of these, both in our Practice and Reading, that we can account for the Causes and Effects of Diseases, and the manner of the Remedies acting, so as to produce their saluterious effects. It is by these, and accurate observations in Practice, that we must improve our Knowledge in the State of Physic and Diseases; it is this Knowledge, and these Abilities, that must be the distinguishing Characteristic of a true Physician, from an Empiric ; it is by this Method of reasoning from Data, founded upon observations and real Facts, that the. Healing Art must be improved and brought to a State of Perfection; for if we once quit our Reason for Mystery, and abandon a just Method of Mechanical and Geometrical Reasoning, for the unintelligible terms of Occult Faculties and Qualities, with all such like Metaphysical and Chymical Jargon and Nonsence, heretofore too much used in the Schools ; we must wander through endless Mazes, and dark Labyrinths, playing at Hazard with Men's Lives, and suffer ourselves to ramble where ever conceited Imagination, or Whymsical Hypothesis will lead us."

We record our sincere thanks to Mrs. A. Wallis, of Darlington, for permission to quote extracts from the letters of Dr. John Fothergill in her possession; and to the librarian of the Friends' Reference Library for help in consulting Quaker records.

C. C. Bоотн.

W. N. Pickles. 